\title{
DR-25
}

\section{PHYSICOCHEMICAL CHARACTERIZATION OF RIBAVIRIN WITH SPECTROSCOPY AND MOLECULAR MODELING}

\author{
K. I. Kienskaya, M. F. Bobrov, A. M. Kusmaev, A. V. Krivitskaya, T. U. Koldaeva, \\ M. V. Sardushkin, R. R.Ibragimova, I. A. Belova, A. V. Kukharenko, G. T. Mazitova, \\ Y. V. Ermolenko and O. V. Zavyalova*
}
Technology of Chemical and Pharmaceutical and Cosmetic Products Division; D.I. Mendeleev University of Chemical Technology of Russia; 125047, Moscow, Miusskaya Sq. 9, Russia *Collegium Medicum im. Ludwika Rydygiera w Bydgoszczy, ul. Jagiellońska 13-15, Bydgoszcz, 85-067 Poland. Tel.: 8903 1166017. E-mail: kienskaya@muctr.ru

Abstract. Ribavirin - (1-beta-D-ribofuranosyl-1H-1,2,4 triazole-3-carboxamine) inhibits the replication of RNA and DNA viruses. In combination with interferon- $\alpha$ used to treat hepatitis $C$ virus, however the mechanism of their synergetic effect is not established [1].

The aim of the present work was to study the interaction with ribavirin and interferon in aqua phase. Ribavirin $(99,8 \%)$ was obtained from Fluka (USA); interferon-alpha-2b was kindly obtained from Biocad Company (Russia, S-Petersburg).

Interferon-ribavirin interactions were studied using affinity capillary electrophoresis (ACE); CD measurements were recorded on Chirascan-Plus spectrometer.

CD spectroscopic technique is useful in monitoring the conformational variations of Interferon in solutions. Our investigations showed that in the presence of ribavirin from $0,14 \mathrm{mMol}$ to $2.98 \mathrm{mMol}$ in mixture solution the quantity of Helix 1 decreased (from 0,38 to 0,27), but quantity of Helix 2 remained constant - about 0,20 (Fig 1).

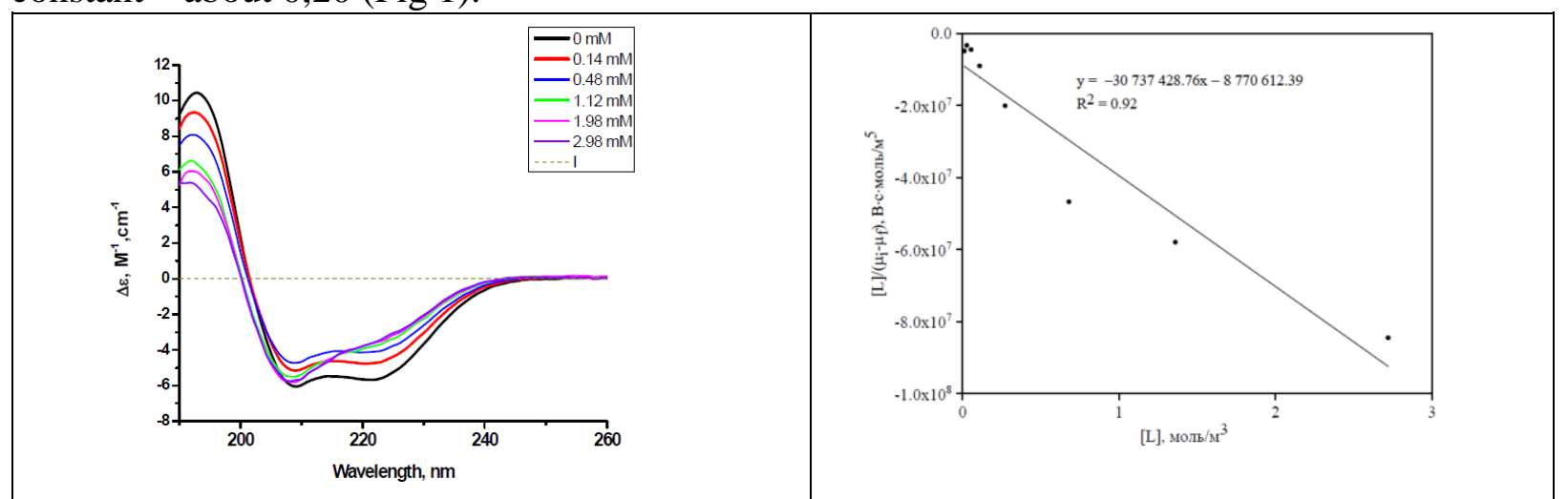

Fig.1. CD-spectra of mixed solutions Ribavirin-Interferon

Fig.2. Scatchard plot of Ribavirin-Interferon interaction from binding profile data using ACE.

The experimental data were approximated by the Hill-model: Complex portion $=x^{n} /\left(x^{n}+K_{d}\right)$, где

$\mathrm{K}_{\mathrm{d}}=\mathrm{k}_{\mathrm{assoc}} \cdot \mathrm{k}_{\text {dissoc. }}=\left(\mathrm{K}_{\mathrm{D}}\right)^{\mathrm{n}}$. The caclculated constant by the CD-methos was $\mathrm{K}_{\mathrm{D}}=0.16 \pm 0.01 \mathrm{mM} ; \mathrm{n}=$ $1.3 \pm 0.1$

Graphical analysis of the profile (ACE-measurements) is show in Fig.2, resulting in one distinct linear plot. The binding constant was calculated by ACE-method with correlation coefficient $0,92 . K_{D}=$ $0.285 \mathrm{mM}$.

These studies may provide a rapid approach for the determination of binding constant RibavirinInterferon and provide some analytical insight into synergetic effect of Ribavirin-Interferon mixture in drug compositions. 